\title{
The Perils of Buying Social Capital Locally
}

\author{
Ryan H. Murphy
}

Southern Methodist University

\begin{abstract}
Among the arguments put forward by proponents of buying local is that it facilitates the accumulation of social capital. However, some research has suggested that social capital may not always confer economic benefits. By this, I mean that too much social capital may lead to adverse outcomes in terms of economic efficiency and the quality of the supporting institutional environment. This paper explores potentially problematic aspects of social capital, especially as they pertain to the buy local movement.
\end{abstract}

JEL Codes: R11, Z10

Keywords: buy local, social capital, informal institutions, trust

\section{Introduction}

Advocates of buying local argue that doing so is beneficial for instrumental reasons. First, for what can be characterized as a "mercantile" rationale, they argue that keeping money in the local economy can make everyone richer, an argument that does not withstand the scrutiny of basic economic analysis (Lusk and Norwood 2011; Gibson 2015). Advocates also claim that buying local has environmental benefits via a smaller environmental footprint, an argument that appears not to be true empirically (McWilliams 2009; Sexton 2009).

This paper explores a third instrumental reason: that buying local causes localities to accumulate social capital, defined as the strength of social networks and the norms and trust that go along with them. ${ }^{1}$ Its importance, championed if not pioneered by Fukuyama (1996) and Putnam (2000), is today almost taken for granted. However, recent research (especially Satayanath, Voigtlaender, and Voth 2017 and Acemoglu, Reed, and Robinson 2014) suggests that indicators we associate with social capital may often have negative effects. While academically the focus has been on the benefits of social capital,

${ }^{1}$ It is not easy to identify an agreed-upon definition of social capital. See Fukuyama (2002) and Bjornskov and Sonderskov (2013); cf. Woolcock (1998). 
among the negative outcomes social capital may produce are "terrorism, organized crime, clientelism, economic inefficiencies, rigid communities that stifle innovation and are dysfunctional within broader societies, ethnic rivalries, and unjust distribution of resources" (Warren 2008, p. 123). Landolt and Portes (1996) presented an earlier statement on the potential problems with social capital, raising issues such as social capital facilitating the exclusion of outsiders. I discuss recent evidence as it relates to buying local and raise other concerns suggesting that, to whatever extent buying local enhances social capital, it may be a net negative. To argue that buying local is instrumentally beneficial because it enhances social capital, one first needs to show that the society does not already have too much of it. It should be noted that Trigilia (2001) first raised the concern that social capital accumulated via buying local may not be unambiguously beneficial, but did so narrowly in terms of market power and its imposition of social pressures against innovation.

It should be emphasized, however, that skepticism toward social capital should not be taken as an argument for atomistic capitalism. Where social capital is not present, individuals do not retreat to be by themselves. They retreat to their families (Banfield 1958; cf. Fukuyama 1996, pp. 61-145). The tension lies in the manner in which the circle of trust is extended beyond the family, not the degree of atomism of the individuals composing the society. Rather than atomism, what is pertinent is whether the relationship between social capital and social welfare is monotonic.

The negative effects of social capital may be thought of in more than one way. Primarily, I will discuss the negative effects of what is generally thought to be beneficial-for example, the interconnectedness of a society. Another possible dimension is that certain social capital may be thought of as being perverse, whereby it actually facilitates criminal activity, as in Rubio (1997). This dimension will arise in section 4, which discusses how buying local may be interpreted as heightening awareness of in-group and outgroup distinctions. However, while these mechanisms differ, they are complementary, not offsetting.

\section{Buying Local and Social Capital}

While social capital as a concept has a long history_dating at least to Tocqueville ${ }^{2}$ - I will focus on its conceptualization by Fukuyama

2 Social capital as a concept also dates to Jacobs (1961). 
(1996) and Putnam (Putnam, Leonardi, and Nanatti 1993; Putnam 2000). Social capital, often measured by civic engagement and associational membership, ${ }^{3}$ creates networks of individuals, enabling trust and large-scale cooperation. Fukuyama claims that social trust explains the remaining 20 percent of economics that neoclassical economics cannot explain (1996, pp. 13-22). And according to Putnam, Leonardi, and Nanatti, "economics does not predict civics, but civics does predict economics, better indeed than economics itself' (1993, p. 157). It has also been argued that social capital, thought of as "informal institutions," deserves the credit often given to formal institutions (Williamson 2009).

Fukuyama sees trust as a means of drastically reducing transaction costs. In low-trust societies like much of Southern Europe, businesses are centered on the family, the group of people safe for an individual to trust. The transaction costs of working with those outside the family are often prohibitively high, preventing cooperation and the gains from trade. Similarly, in China, firms cannot last long, since, out of a lack of trust, they are never handed over to professional managerial teams. Instead, once the founder retires or passes away, the firm's fortunes are in the hands of the founder's children, who may not be of the same entrepreneurial quality. The failure of firms to scale to the size one sees in high-trust societies like Germany and the United States is a substantial static cost that prevents otherwise modernized societies from reaching the technological frontier.

Putnam argues more generally that social capital underlies the quality of institutions. Social context shapes the performance of institutions, which ultimately leads to social outcomes. In their foundational work, Putnam, Leonardi, and Nanatti (1993) find that differences in outcomes between states in Northern Italy and Southern Italy, where much else is held constant, are explained by their differences in civic traditions. Civically engaged networks of citizens enable accountable governance, which in turn enables economic performance and other social improvements.

Buying local, whether by familiarity, empathy, or repeated dealings, is said to build trust and to enhance social capital. Typically, encouraging the accumulation of social capital is difficult; simple subsidies for civic organizations have unclear and possibly negative effects (Rothstein 2005, pp. 92-128). A keyhole solution for

${ }^{3}$ See van Deth (2008) for a full discussion of its measurement. 
accumulating social capital would thereby be of great interest in public policy. The literature on buying local and social capital claims to have found that solution. Feenstra (1997) argues that local food systems with desirable characteristics "enhance social equity and democracy for all members of the community." She explores several means of encouraging local food so as to combat agribusiness and the corporate control that impair communities, according to other authors she cites.

Goetz and Rupasingha (2006) argue that empirically, the presence of Walmart reduces social capital stocks because it "responds to market opportunities and by definition ignores the local externalities it creates within communities." Using an instrumental variable technique, they find that the initial number of stores and each added store per 10,000 people negatively impact social capital, as measured by an index comprised of associations per 10,000, presidential voting in the 2000 election, nonprofits per 10,000, census participation, and church adherence. The number of stores reduces the index by about 10 percent of a standard deviation per 10,000 and the additional store per 10,000 reduces it by 15 percent of a standard deviation. ${ }^{4}$

Blanchard and Matthews (2006) find that the local economic concentration of corporate establishments reduces electoral participation and protest activities, because, they argue, "economic concentration leads to a monolithic power structure and generates civic apathy because the needs of the corporation override those of the local population." To do so, they construct an index using the Herfindahl Index and other metrics and run regressions with the index of economic concentration as an independent variable. For dependent variables, the authors use two other indexes constructed from survey questions. The first centers on electoral politics, asking questions including interest in politics and whether the individual voted in the 1992 election. The second centers on protest politics, asking questions including participation in political rallies and union membership. The degree of economic concentration corresponds to lower scores on these indexes, which the authors argue is evidence that concentration reduces social capital.

Finally, Blanchard, Tolbert, and Mencken (2011) argue that the presence of small businesses improves community health via their effects on social capital. The small businesses signify "entrepreneurial culture [which] facilitates collective efficacy for a community and

${ }^{4}$ Carden, Courtemanche, and Meiners (2009) dispute these results. 
provides a problem-solving capacity for addressing local public health problems." In fixed effects weighted least squares regressions, they find that the number of businesses with 0-4 employees per 100,000, the proportion of the population that is part of the creative class, and the proportion of the population that is part of the Bohemian class (those employed in the arts and entertainment occupations) have beneficial impacts on age-adjusted mortality, obesity rate, and the percentage of the population that is diabetic. Meanwhile, the number of large retailers per 100,000 has detrimental effects on two of the measures and a statistically insignificant impact on the third. The authors are explicit that the channel by which the gains are achieved is via "enhanced stocks of social capital and collective efficacy."

Given the emphasis on community building and the scope of the local found in these studies, it is likely correct to interpret these studies as arguing that buying local builds bonding social capital, as opposed to building bridging social capital (as in Szreter and Woodcock 2004). That is to say, if buying local builds social capital, it does so in such a way that buttresses the linkages within the group (i.e., the community), as opposed to creating bridges across groups. Throughout this paper, the relevant form of social capital is bonding social capital. If it were the case that, paradoxically, buying local engendered stronger cosmopolitan-instead of communitarianmores, then the case made here would be greatly diminished.

As an important side note, I wish to point out that there is a tension between Fukuyama's rationale for social capital and the accumulation mechanism of buying local: buying local requires lowscale cooperation, but Fukuyama's theory of social capital is that it allows for large-scale cooperation. This conflict-why it is a positive for economies to be able to cooperate at a large scale and create multinational corporations, but social capital is to be accumulated in very small, localized firms-has not been acknowledged. While it could be argued that both large-scale cooperation within corporations and buy local consumption patterns are simultaneously beneficial, this argument is not reflected in the literature cited previously, or elsewhere in the buy local movement.

Regardless, if social capital underlies both our economy and polity, and if buying local enhances social capital, it may appear that there is a clear instrumental benefit to buying local. However, if there are also drawbacks to the presence of social capital, and especially if the relationship between social capital and economic welfare is not 
monotonic, then a net benefit may not exist. The remainder of this paper will explain why.

\section{Deadweight Loss Associated with Social Capital}

For two reasons, the presence of social capital may generate deadweight loss. The first, mentioned by Trigilia (2001), is that buying local may grant monopoly power. This idea may sound counterintuitive, since large firms are most associated with monopoly power, but a monopoly in a national market is not the same as a monopoly in a local market. A hardware store in a rural town may have more market power than a national-level duopoly because any alternative is excessively costly for many citizens of the town. The possibility that a national hardware chain will move in transforms the situation into that of a contestable market (as in Baumol, Panzar, and Willig 1982). A credible buy local campaign, even in the absence of mobilizing the local government, may discourage locals from patronizing the national chain. In limiting the number of potential entrants, more market power may be present under the buy local regime than when allowing outside firms to compete on their own merits.

The second source of deadweight loss is a bit more complex and relates to Fukuyama's point about how social capital reduces transaction costs. In low-social-capital societies, family members strictly favor one another over outsiders. This preference is of little importance in the absence of transaction costs, as the gains from trade will still occur. But if individuals believe that outsiders will cheat or prey on them, then costs must be incurred for them to enter into the transaction.

According to Fukuyama, the development of social trust to escape these costs is not the result of a rational choice mechanism; the reasons are sociological. Economic actors must not be the opportunistic homo economicus to allow for large-scale cooperation, ${ }^{5}$ as observed in the development of towering corporate entities. In Japan, we see the keiretsu (business groups) and peculiar labor-market institutions that have developed as a result of very high levels of social capital. Enabling workers to cooperate at this scale certainly confers benefits to an economy when such scale is efficient.

\footnotetext{
5 To be precise, by "homo economicus," I mean that the individuals are relentlessly opportunistic toward outsiders. Members of low-trust societies still favor members of their family.
} 
However, their peculiarity also points to their trade-off. Lifetime employment and paternalistic employers, while receding, are hallmarks of business life in Japan (Economist 2008). Layoffs are taboo; to avoid them, employers will send workers to "banishment rooms" in the hope that the employees will quit (Tabuchi 2013). While many of these practices will not withstand further opening of the country to international competition (Smith 2013), they have persisted decades or longer. Trust may have allowed Japanese firms to cooperate at a scale seen little elsewhere in the world, but it has also encouraged inappropriate, inefficient practices and institutions that inhibit Japan today. ${ }^{6}$

One way of conceptualizing this system is in terms of Fiske's (1992) model of social relations. When social trust is low, social actors (except within the family) employ pure, impersonal, costbenefit analysis of the social relation of market pricing. Its impersonality promotes a colder, more calculated rationality, which is beneficial in some contexts, but it may reduce the psychic costs of cheating. When social trust is high, transactions take on characteristics of other social relations, such as equality matching, where the group strives for balance across its members. If equality matching is salient, each actor may be trusted not to cheat, but may not want to single out specific employees to be laid off even though profit maximization demands it.

Thus, when there is too little trust, economic actors are unable to cooperate at the scale theory predicts due to transaction costs. Since the level of trust is exogenous ex ante for economists, theory is unable to predict when transaction costs will be too high for economic actors to cooperate as they "should." Given economists" lack of visibility into trust, the failure of low-trust societies to create large firms is likely best thought of as a form of $X$-inefficiency, even though what it amounts to is a specific form of transaction cost.

\footnotetext{
${ }^{6}$ Another framing is not whether there is too much social capital, but whether the social capital is liberal in character (Carden 2009; Hagreaves Heap 2008). In the current context, if deep interconnectedness at high levels continues to facilitate cooperation, but liberal-mindedness reinforces the norms of markets, then the issues raised in this section are largely mitigated. However, broadly speaking, as social capital is conventionally measured, the contention here is that very high levels are correlated with worse outcomes.

7 Per Coase, firms would not exist in the absence of transaction costs. The transaction costs relevant here are those resulting from a lack of trust, not the ability to enter contracts instantaneously and costlessly.
} 
In contrast, when there is too much trust, firms depart from profit maximization, as is seen among Japanese firms. Under sufficient competition, these departures would cease. However, to the extent that they persist (as a result of non-tradeables or frictions), they represent a form of $X$-inefficiency. The optimal level of social capital thus minimizes $X$-inefficiency summed across both margins. One possibility, modeling the pair of problems similarly to a Laffer curve, is found in figure 1 . This model implicitly contradicts Putnam's argument that we should see only two equilibria in social trust, but is consistent with how social trust is measured generally as a continuum.

\section{Figure 1. The Social Capital "Laffer Curve"}

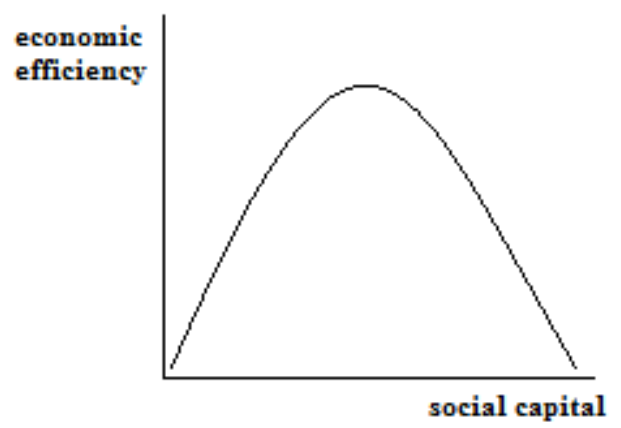

Other costs of buying local, such as increasing market power, may be thought of as shifting this curve to the left. The welfaremaximizing point on the curve is contingent on other assumptions about social capital. If social capital serves no intrinsic purpose (as opposed to serving a purpose instrumentally), but social capital is costly to invest in, then the optimal level of social capital is some point to the left of the curve. If social capital both serves an intrinsic purpose and is costless, the optimal level of social capital is on the right of the curve. Otherwise, the optimal point on the curve is indeterminate. Regardless, the case for social capital is not as strong as it may initially appear, whether accumulated via buying local or other methods.

To illustrate, though not rigorously test, this relationship, I ran regressions placing logged real GDP per capita, PPP adjusted, from World Development Indicators on the left-hand side, explained by the "informal institutions" measure from Williamson (2009) and its squared term. I also used capital per worker from Baier, Dwyer, and Tamura (2006) and years of education from the Barro and Lee (2013) data set. All data are from the year 2000 because it is the most recent 
year for capital per worker and the choice of year is inherently arbitrary, as Williamson's data is cross sectional and not year specific. The sample size is restricted to seventy-two, primarily due to the lack of countries covered by the measure of informal institutions.

Table 1 provides the results. Regression 1 provides a baseline, showing a positive, statistically significant linear relationship between the informal institutions measure and output. Regression 2, however, finds a negative sign on the quadratic term. Subsequently, regressions 3 to 5 include human capital, capital per worker, and then both, with the qualitative relationship found in regression 2 unchanged.

Table 1. Regression Results, Quadratic Effects on Log GDP per capita, PPP

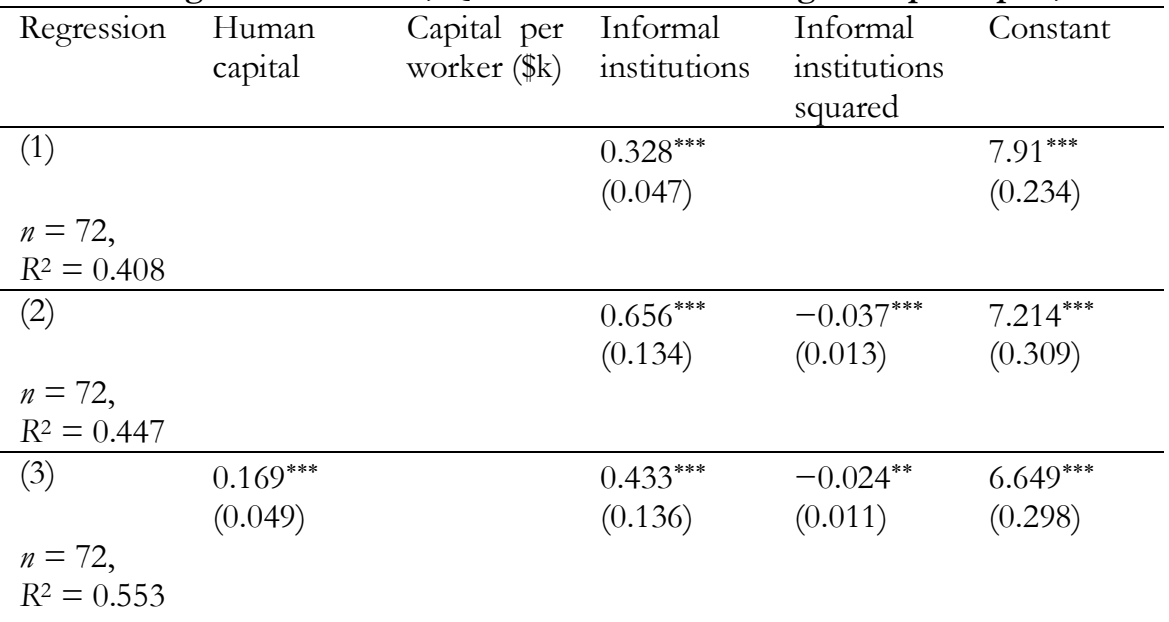

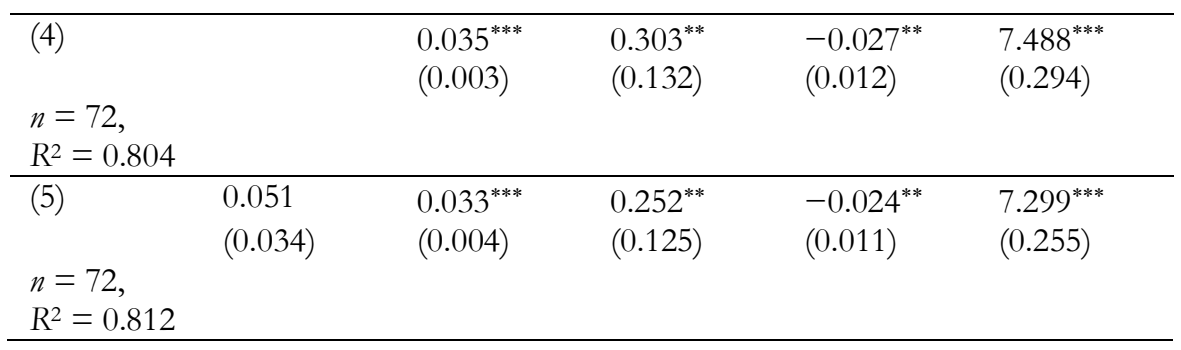

Note: Standard errors are robust. ${ }^{* *}$ denotes $p<0.05 ;{ }^{* * *}$ denotes $p<0.01$.

Under specifications 2 to 4, I do find the "Laffer curve" relationship. In regression 5, the implied Laffer curve peaks at 5.25, a score that is 0.41 standard deviations better than average. For points of comparison, the United States scores 6.75, Germany scores 6.63, and Japan scores 6.76. To help visualize this point, I ran a separate regression using only the control variables on the right-hand side and 
graphed the residuals against the informal institutions measure, then drawing the best quadratic line of fit, as figure 2 shows. Again, neither table 1 nor figure 2 are meant to be more than illustrations of empirical plausibility.

Figure 2. Informal Institutions and Residuals from Baseline Income Level Regression

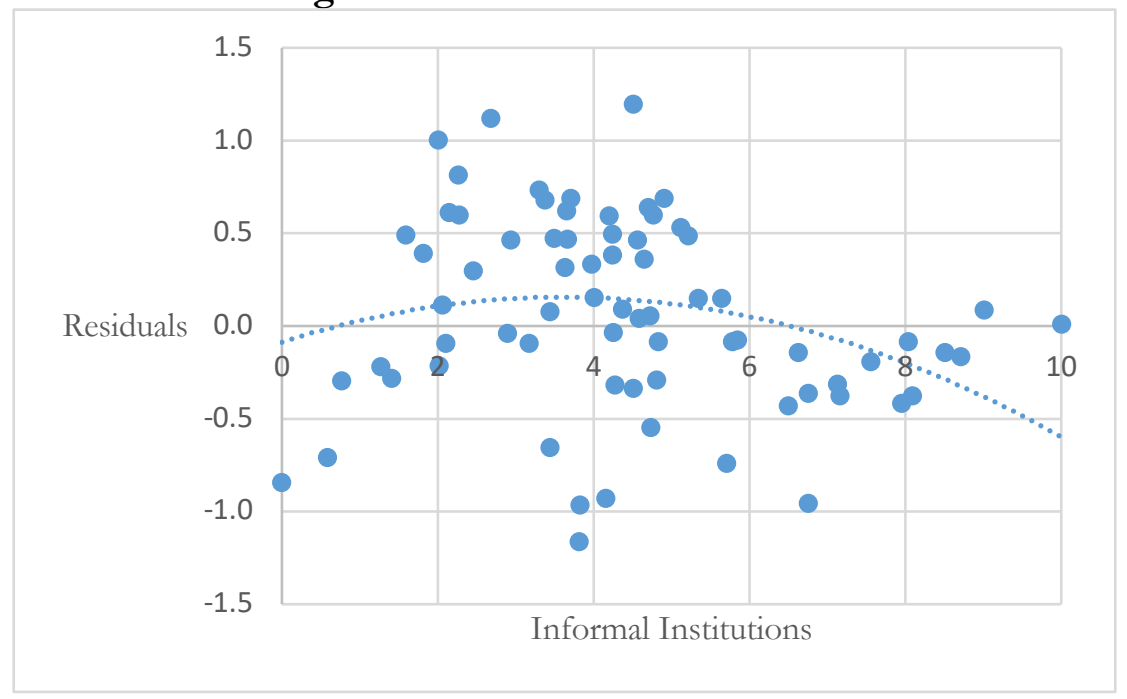

Social capital, especially as conceived of by Fukuyama, is a variable ostensibly unrelated to economic life, and Fukuyama sees it as lying outside the scope of economics entirely. Thus, the economic way of thinking should be that, like anything, social capital is something with both costs and benefits, and its marginal benefits will diminish as it is accumulated. This discussion has outlined one particular way social capital's benefits may diminish to the point of interfering with the efficient allocation of scarce resources, with the motivating example of labor markets in Japan along with some basic empirics.

\section{Political Economy Considerations}

Beyond introducing deadweight loss into the economy, high levels of social capital may damage political institutions, contrary to Putnam's arguments. Social capital may encourage autarkic policies if in-group solidarity and out-group hostility are the two heads of the same coin. High levels of social trust may also allow political leaders to co-opt civil society organizations and form clientelistic relationships with the 
businesses deemed important for buying local. Setting aside static inefficiencies, we should be skeptical of buying local if it skews policy toward autarky and romantic industrial policy.

Social trust, at its base, functions through reciprocity. We typically see this reciprocity positively, but it may also lead to people being willing to greatly harm outsiders. One way of thinking about social capital is that it binds the "in-group" together. Simultaneously, it may also increase the willingness to mobilize against the "outgroup." While they need not always go together, "the very factors that make ingroup attachment and allegiance important to individuals also provide fertile ground for antagonism and distrust of those outside the ingroup boundaries" (Brewer 1999). Another way of putting it is that means of enhancing in-group solidarity may also sharpen hostility toward the out-group (see Hargreaves Heap 2008). Ultimately, the community governance that social trust confers "typically relies on insider-outsider distinctions that may be morally repugnant and economically costly" (Bowles and Gintis 2002). Putnam himself (2007) has argued that the arrival of outsiders (immigration) reduces social capital through these same mechanisms.

Satayanath, Voigtlaender, and Voth (2017) illustrate this point. Social capital in Nazi Germany, as measured by civil association membership, predicts Nazi party membership. Contrary to other literature, they find that civic society facilitated Hitler's rise to power. The authors emphasize that social capital was especially well mobilized for the Nazis where governments were changing rapidly and thus perhaps weak. But while strong political institutions (almost definitionally) may curtail political parties favoring the total destruction of liberal democracy, the link between social capital and hostility toward outgroups remains.

Nazism was, at least to some extent, a small-business movement (Winkler 1976). Under this framework, social capital breeds populism and a romance of the plight of those you see each day. To this end, Germany sought autarky and the extermination of the out-group. I do not accuse the buy local movement of pursuing genocide, but if social capital promotes out-group hostility, then social capital through buying local may mean exclusion of outgroups (if not foreigners, then corporations) in the same sense and with the same underlying psychology. "Buy Local" is a voluntary association that, unlike associations that build general social trust, is very much based on what Rothstein calls the "logic of separation" (2005, p. 101) and thus is prone to generating these hostilities. After all, if buying local is 
virtuous and must be done emphatically, what does that say about non-local firms?

For a separate reason, high levels of social capital may directly subvert the institutions Putnam argues it improves. Acemoglu, Reed, and Robinson (2014) show that in Sierra Leone, measures of social capital correlate positively with respect for ruling families but negatively with development outcomes. The authors interpret this finding to mean that social capital enables leaders to control those they govern. They go as far as arguing, in fact, that international interventions meant to strengthen civil society may primarily work to strengthen local chiefs who will fail to provide public goods and simply engage in clientelistic relationships.

This phenomenon may not be limited to the developing world. High levels of social capital in Japan may allow its government to coopt labor organizations into pursuing the government's priorities (Broadbent 2000). Analogously, social trust may encourage a kind of clientelism, as Japan has been historically reluctant to unleash competitive forces on its own small businesses; mom-and-pop stores have sometimes been at the forefront of the opposition to liberalization (Porter and Sakakibara 2004). Writ small, this type of clientelism may be seen in the ban on fast food in South Los Angeles (Chandler 2015) or Boston's fight against Walmart (Anderson 2011). Though large corporations may often use the political system to seek gifts and privileges, social capital bought locally may encourage the opposite issue to arise.

\section{Conclusion}

While academics have come to a near consensus on the importance of social capital, there are good reasons to believe that its relationship with social well-being is not monotonically positive. More likely, there is a "Laffer curve" relationship. This relationship means that, even if we accept that buying local enhances social capital, buying local may not be instrumentally desirable. Artificially limiting the number of potential entrants into a market, as the buy local movement intends, often increases market power, even if one of the potential entrants has a large market share nationwide. Social capital may introduce $X$-inefficiency into an economy, as illustrated by labor markets in Japan. Social capital may encourage autarkic economic

\footnotetext{
8 This, too, is reflective of the interpretation of buying local as accumulating bonding social capital, not bridging social capital.
} 
policy, since it potentially leads to greater hostility toward the outgroup as it promotes solidarity in the in-group. Finally, despite Putman's arguments, there is evidence that high levels of social capital may damage the quality of political institutions, creating opportunities for clientelism at the local level.

There are many possible ways of accumulating social capital. Some methods (or measures of social capital itself), like volunteering, often take the appearance of a morality play. Of course, the morality plays may possess elements of truth. In this paper, I do not question the standard means of accumulating social capital, but a more obscure one. But while volunteering may uncontroversially have intrinsic value, buying local requires an instrumental justification unless autarky has intrinsic value. Unless it can be shown that advanced economies do not already possess too much social capital, the argument that buying local is beneficial because it confers social capital is a failed morality play for autarky.

\section{References}

Acemoglu, Daron, Tristan Reed, and James A. Robinson. 2014. "Chiefs: Economic Development and Elite Control of Civil Society in Sierra Leone." Journal of Political Economy, 122(2): 319-68.

Anderson, Rob. 2011. "Menino's Solitary Fight against Urban Wal-Marts." Boston.com, February 11.

Baier, Scott L., Gerald P. Dwyer, and Robert Tamura. 2006. "How Important Are Capital and Total Factor Productivity for Economic Growth?" Economic Inquiry, 44(1): 23-49.

Banfield, Edward C. 1958. The Moral Basis of a Backward Society. Glencoe, IL: Free Press.

Barro, Robert, and Jong Wha Lee. 2013. "A New Data Set of Educational Attainment in the World, 1950-2010." Journal of Development Economics, 104: 184-98.

Baumol, William J., John C. Panzar, and Robert D. Willig. 1982. Contestable Markets and the Theory of Industrial Structure. New York: Harcourt, Brace, and Jovanovich.

Bjornskov, Christian, and Kim Mannemar Sonderskov. 2013. "Is Social Capital a Good Concept?" Social Indicators Research, 114(3): 1225-42.

Blanchard, Troy C., and Todd L. Matthews. 2006. "The Configuration of Local Economic Power and Civic Participation in the Global Economy." Social Forces, 84(4): 2241-57.

Blanchard, Troy C., Charles Tolbert, and Carson Mencken. 2011. "The Health and Wealth of US Counties: How the Small Business Environment Impacts Alternative Measures of Development." Cambridge Joumal of Regions, Economy, and Society, 5(1): 149-62.

Bowles, Samuel, and Herbert Gintis. 2002. "Social Capital and Community Governance.” Economic Journal, 112: F419-36. 
Brewer, Marilynn B. 1999. "The Psychology of Prejudice: Ingroup Love and Outgroup Hate?” Journal of Social Issues, 55(3): 429-44.

Broadbent, Jeffrey P. 2000. "Social Capital and Labor Politics in Japan: Cooperation or Cooptation?" Policy Sciences, 33(3-4): 307-21.

Carden, Art. 2009. "Inputs and Institutions as Conservative Elements." Review of Austrian Economics, 22(1): 1-19.

Carden, Art, Charles Courtemanche, and Jeremy Meiners. 2009. "Does Wal-Mart Reduce Social Capital?” Public Choice, 138(1-2): 109-36.

Chandler, Adam. 2015. "Why the Fast-Food Ban Failed in South L.A." Atlantic, March.

Economist. 2008. "Sayonara, Salaryman," January 3.

Feenstra, Gail W. 1997. "Local Food Systems and Sustainable Communities." American Journal of Alternative Agriculture, 12(1): 28-36.

Fiske, Alan P. 1992. "The Four Elementary Forms of Sociality: Framework for a United Theory of Social Relations." Psychological Review, 99(4): 689-723.

Fukuyama, Francis. 1996. Trust: The Social Virtues and the Creation of Prosperity. New York: Free Press.

Fukuyama, Francis. 2002. "Social Capital and Development: The Coming Agenda." SAIS Review, 22(1): 23-37.

Gibson, Warren C. 2015. "Why Buy Local? The Seen and the Unseen at Your Local Food Market.” Freeman, May 10.

Goetz, Stephen J., and Anil Rupasingha. 2006. "Wal-Mart and Social Capital." American Journal of Agricultural Economics, 88(5): 1296-1303.

Hargreaves Heap, Shaun P. 2008. "Social Capital and Snake Oil." Review of Austrian Economics, 21(2): 199-207.

Jacobs, Jane. 1961. The Death and Life of Great American Cities. New York: Random House.

Landolt, Patricia, and Alejandro Portes. 1996. "The Downsides of Social Capital." American Prospect, 26(May-June): 18-26.

Lusk, Jayson L., and F. Bailey Norwood. 2011. “The Locavore's Dilemma: Why Pineapples Shouldn't Be Grown in North Dakota." Library of Economics and Liberty Featured Article, January 3.

McWilliams, James E. 2009. Just Food: Where Locavores Get It Wrong and How We Can Truly Eat Responsibly. New York: Little, Brown.

Porter, Michael E., and Mariko Sakakibara. 2004. "Competition in Japan." Journal of Economic Perspectives, 18(1): 27-50.

Putnam, Robert D. 2000. Bowling Alone: The Collapse and Revival of American Community. New York: Simon \& Schuster.

Putnam, Robert D. 2007. "E Pluribus Unum: Diversity and Community in the Twenty-First Century: The 2006 Johan Skytte Prize Lecture." Scandinavian Political Studies, 30(2): 134-74.

Putnam, Robert D., Robert Leonardi, and Raffaella Y. Nanatti. 1993. Making Democracy Work: Civic Traditions in Modern Italy. Princeton, NJ: Princeton University Press.

Rothstein, Bo. 2005. Social Traps and the Problem of Trust. New York: Cambridge University Press.

Rubio, Mauricio. 1997. "Perverse Social Capital: Some Evidence from Colombia." Journal of Economic Issues, 31(3): 805-16. 
Satayanath, Shanker, Nico Voigtlaender, and Hans-Joachim Voth. 2017. "Bowling for Fascism: Social Capital and the Rise of the Nazi Party." Journal of Political Economy, 125(2): 478-526.

Sexton, Steven. 2009. "Does Local Production Improve Environmental and Health Outcomes?" Agricultural and Resource Economics Update, 13(2): 5-8.

Smith, Noah. 2013. “Japan's Last Chance: Abe Embraces Neoliberalism." Foreign Affairs Snapshot, November 12.

Szreter, Simon, and Michael Woodcock. 2004. "Health by Association? Social Capital, Social Theory, and the Political Economy of Public Health." International Journal of Epidemiology, 33(4): 650-67.

Tabuchi, Hiroko. 2013. "Layoffs Taboo, Japan Workers Are Sent to the Boredom Room." New York Times, August 16.

Trigilia, Carlo. 2001. "Social Capital and Local Development." European Journal of Social Theory, 4(4): 427-42.

van Deth, Jan. 2008. "Measuring Social Capital." In The Handbook of Social Capital, ed. Dario Castiglone, Jan W. Van Deth, and Guglielmo Wooleb, 150-76. New York: Oxford University Press.

Warren, Mark E. 2008. "The Nature and Logic of Bad Social Capital." In The Handbook of Social Capital, ed. Dario Castiglone, Jan W. Van Deth, and Guglielmo Wooleb, 122-49. New York: Oxford University Press.

Williamson, Claudia. 2009. "Informal Institutions Rule: Institutional Arrangements and Economic Performance." Public Choice, 139(3): 371-84.

Winkler, Heinrich August. 1976. "From Social Protectionism to National Socialism: The German Small-Business Movement in Comparative Perspective." Journal of Modern History, 48(1): 1-18.

Woolcock, Michael. 1998. "Social Capital and Economic Development: Toward a Theoretical Synthesis and Policy Framework." Theory and Society, 27(2): 151208. 